\title{
Lipopolysaccharide (LPS) potentiates hydrogen peroxide toxicity in T98G astrocytoma cells by suppression of anti-oxidative and growth factor gene expression
}

\author{
Gang Yue ${ }^{\dagger 1}$, Guanfang Shi ${ }^{\dagger 2}$, Marco A Azaro ${ }^{1}$, Qifeng Yang1, Guohong $\mathrm{Hu}^{1}$, \\ Minjie Luo ${ }^{1}$, Kingsley Yin ${ }^{3}$, Robert G Nagele ${ }^{4}$, Daniel H Fine ${ }^{5}$, Jin-Ming Yang ${ }^{6}$ \\ and Honghua $\mathrm{Li}^{* 1}$
}

\begin{abstract}
Address: ${ }^{1}$ Department of Molecular Genetics, Microbiology and Immunology/The Cancer Institute of New Jersey, University of Medicine and Dentistry of New Jersey Robert Wood Johnson Medical School, Piscataway, New Jersey 08854, USA, 2Department of Chemical Biology, Ernest Mario School of Pharmacy, Rutgers University, Piscataway, NJ 08854, USA, ${ }^{3}$ Department of Cell Biology, University of Medicine and Dentistry, NJ-School of Osteopathic Medicine, Stratford, NJ 08084, USA, ${ }^{4}$ New Jersey Institute for Successful Aging, University of Medicine and Dentistry of New Jersey School of Osteopathic Medicine, Stratford, NJ 08084, USA, ${ }^{5}$ Department of Oral Biology, New Jersey Dental School, University of Medicine and Dentistry, Newark, NJ 07101, USA and ' Department of Pharmacology, Cancer Institute of New Jersey, New Brunswick, NJ 08901, USA

Email: Gang Yue - yue@umdnj.edu; Guanfang Shi - guanfang@rci.rutgers.edu; Marco A Azaro - azaro@biology.rutgers.edu; Qifeng Yang - qifengy@gmail.com; Guohong Hu - guohongh@Princeton.Edu; Minjie Luo - minjie.luo@mssm.edu; Kingsley Yin - yinki@umdnj.edu; Robert G Nagele - nagelero@umdnj.edu; Daniel H Fine - finedh@umdnj.edu; JinMing Yang - jyang@umdnj.edu; Honghua Li* - holi@umdnj.edu

* Corresponding author †Equal contributors
\end{abstract}

Published: 16 December 2008

BMC Genomics 2008, 9:608 doi:10.1/86/|47|-2164-9-608
Received: I August 2008

Accepted: 16 December 2008

This article is available from: http://www.biomedcentral.com/I47I-2 I64/9/608

(C) 2008 Yue et al; licensee BioMed Central Ltd.

This is an Open Access article distributed under the terms of the Creative Commons Attribution License (http://creativecommons.org/licenses/by/2.0), which permits unrestricted use, distribution, and reproduction in any medium, provided the original work is properly cited.

\begin{abstract}
Background: Lipopolysaccharide (LPS) is a cell wall component of Gram-negative bacteria with proved role in pathogenesis of sepsis. Brain injury was observed with both patients dead from sepsis and animal septic models. However, in vitro administration of LPS has not shown obvious cell damage to astrocytes and other relative cell lines while it does cause endothelial cell death in vitro. These observations make it difficult to understand the role of LPS in brain parenchymal injury.

Results: To test the hypothesis that LPS may cause biological changes in astrocytes and make the cells to become vulnerable to reactive oxygen species, a recently developed highly sensitive and highly specific system for large-scale gene expression profiling was used to examine the gene expression profile of a group of I, I35 selected genes in a cell line, T98G, a derivative of human glioblastoma of astrocytic origin. By pre-treating T98G cells with different dose of LPS, it was found that LPS treatment caused a broad alteration in gene expression profile, but did not cause obvious cell death. However, after short exposure to $\mathrm{H}_{2} \mathrm{O}_{2}$, cell death was dramatically increased in the LPS pretreated samples. Interestingly, cell death was highly correlated with down-regulated expression of antioxidant genes such as cytochrome b56 I, glutathione s-transferase a4 and protein kinase C-epsilon. On the other hand, expression of genes encoding growth factors was significantly suppressed. These changes indicate that LPS treatment may suppress the anti-oxidative machinery, decrease the viability of the T98G cells and make the cells more sensitive to $\mathrm{H}_{2} \mathrm{O}_{2}$ stress.

Conclusion: These results provide very meaningful clue for further exploring and understanding the mechanism underlying astrocyte injury in sepsis in vivo, and insight for why LPS could cause astrocyte injury in vivo, but not in vitro. It will also shed light on the therapeutic strategy of sepsis.
\end{abstract}




\section{Background}

Sepsis is a grave threat to human life in the modern society. It is listed as the second most common cause of death in non-coronary intensive care units and is among the top causes leading to death in the United States [1,2]. The severity of the pathogenesis of sepsis was thought to be the consequence of an uncontrolled hyperinflammatory and mostly cytokine-mediated host response. Recently, a new theory was proposed, which emphasizes on the virulence of microbial pathogens and host-pathogen interactions during severe sepsis [2,3]. A number of extracellular enzymes and microbial mediators have been identified contributing to tissue damage in sepsis. These toxins compromise cellular defenses, cause damage in barriers for microbial invasion, and help the pathogens to spread within the host. In the spectrum of pathogenesis of sepsis, lipopolysaccharide (LPS) has been considered to play a crucial role in pathogen-host interaction [2]. LPS is a major structural component of the outer membrane of Gram-negative bacteria, so as to be often referred as an endotoxin.

Brain injury is observed in postmortem examination of patients dead from sepsis with lesions of multifocal necrotizing leukoencephalopathy, apoptosis, micro-abscesses, and ischemia $[4,5]$. Systemic LPS administration led to granulocyte influx into brain parenchyma in a mouse model. This influx was accompanied by disruption of the blood-brain barrier to albumin and induction of the intracellular adhesion molecule 1 (ICAM-1) on affected blood vessels [6]. Brain cell death, but no polymorphonuclear infiltration, was also observed in some autopsy materials of patients who died of septic shock [7]. These observations implicate multiple pathways that may underlie the brain cell death process. Brain cell injury could be one of the direct causes leading to septic patient death. For instance, neuronal apoptosis in autonomic centers i.e. cardiovascular autonomic centers indicates that the septic pathogens may set off host mortality by means of damaging host brain cells $[4,8]$.

In the blood-brain barrier, endothelial cells are the first interface interacting with hematogenous spreading LPS. LPS damage to endothelial cells was shown in many studies, one of which showed that LPS induced apoptosis in a bovine endothelial cell line via a soluble CD14 dependent pathway [9]. LPS also induce apoptosis in human endothelial cells [10]. Brain endothelial cell damage during septic shock has also been noticed in clinical patients [11]. LPS triggering brain cell death was observed by de Bock and coworkers [12], who found that LPS endotoxic insult caused neuronal death in cultured organotypic hippocampal slices obtained from 7-day old neonatal rats dependent on the synthesis of tumor necrosis factor alpha $(\mathrm{TNF}-\alpha)$ [12]. LPS was also reported to induce death of glial cells in freshly isolated rat neonatal white matter in a dose-dependent fashion [13]. LPS encephalic injection induced endothelial cell and astrocyte injury with increase in blood-brain barrier permeability in rat models [14]. LPS astrocyte injury was also indicated in large animals in vivo. Oikawa and coworkers [15] found that septic shock, featured as edema around arterioles and hemorrhages around veins in the brain of horses after systemic administration of LPS [15]. Astrocytes are mainly layered around the blood vessels in the brain. The edema and hemorrhage zones indicate the involvement of astrocytes.

Astrocytes (astroglia) are a subtype of the glial cells in the brain and star-shaped with many functions, including biochemical support of endothelial cells forming the blood-brain barrier, provision of nutrients to the nervous tissue, and a principal role in the repair and scarring process. Astrocytes are the major type of cells around blood vessels in the brain and form the blood-brain barrier with blood vessel endothelial cells. Therefore, in systemically induced or infected endotoxemia, astrocytes will be the direct defense-line of the brain after endothelium being compromised to LPS. When the defensive line of astrocytes is compromised, the brain parenchyma becomes very susceptible to pathogen infection. While LPS causes endothelial cell death both in vivo and in vitro [14,16,17], astrocyte derivative cell lines such as human cell lines T98G and A172, rat cell lines C6 and immortalized rat astrocytes are broadly used in LPS treated experiments, and no cell injury has been reported $[18,19]$. If LPS does not cause astrocyte injury in vitro, how could LPS cause astrocyte injury in vivo in the animal tests? Whether systemic administration of LPS could result in brain parenchyma damage also becomes a question.

Previous publications indicate that LPS alone would not cause cell death, but LPS combined with cytokines, i.g., interferon- $\gamma$ (INF- $\gamma$ ) would cause decrease in viability of rat C6 and rat primary astrocytes $[20,21]$. Those reports indicate a much more complex mechanism of LPS on astroctyte injury compared to LPS causing endothelial injury. LPS is involved in broad inflammatory responses. Therefore, a comprehensive study of inflammation and other relevant factors under LPS influence may provide more detailed information about the behavior of astrocytes in sepsis.

The present study was designed to explore LPS role in sepsis in a comprehensive way by profiling expression of a highly selected group of genes using an astrocyte model (T98G). T98G cell line is a derivative of glioblastoma. Its astrocytic origin was confirmed by Bignami et al. [22]. The cell line has been intensively used as a model to study astrocytes [23-25] because of its biological resemblance to primary astrocyte. T98G cells express the specific marker 
of astrocyte, glial fibrillary acidic protein (GFAP) and share other phenotypes to primary astrocyte such as CD68- and HLA-I' [24].

\section{Results \\ LPS potentiates $\mathrm{H}_{2} \mathrm{O}_{2}$-caused cell death}

Without subsequent $\mathrm{H}_{2} \mathrm{O}_{2}$ exposure, cellular viability was not altered when cells were treated with $1 \mu \mathrm{g} / \mathrm{ml}$ LPS compared to PBS controls (First panels on the left in Figure 1A and $1 \mathrm{~B})$. With higher concentration of LPS $(5 \mu \mathrm{g} / \mathrm{ml})$, it only caused a minor $(5 \%)$ reduction of cell viability compared to the PBS controls without subsequence $\mathrm{H}_{2} \mathrm{O}_{2}$ exposure (First panels on the left in Figure. 1A and 1B).

By itself, $\mathrm{H}_{2} \mathrm{O}_{2}$ caused substantial cell death, but this effect was greatly enhanced in cells pretreated by LPS (Figure 1). $\mathrm{H}_{2} \mathrm{O}_{2}$ mediated decrease in cell viability was closely related to LPS dose. $1 \% \mathrm{H}_{2} \mathrm{O}_{2}$ treatment caused 36\% decrease in cell viability among the cells pretreated with 1 $\mu \mathrm{g} / \mathrm{ml} \mathrm{LPS}$, while $5 \mu \mathrm{g} / \mathrm{ml}$ LPS caused $50 \%$ decrease in cell viability, as compared to the corresponding cells which only treated with LPS without subsequent $\mathrm{H}_{2} \mathrm{O}_{2}$ treatment. In contrast, cell viability only dropped $24 \%$ for cells that did not receive LPS beforehand. Similar patterns were obtained in groups treated with $2 \%$ and $3 \% \mathrm{H}_{2} \mathrm{O}_{2}$.

In all subgroups treated with $\mathrm{H}_{2} \mathrm{O}_{2}$, cell viabilities were significantly reduced $(\alpha<0.05)$ in the groups pretreated with LPS at as low as $1 \mu \mathrm{g} / \mathrm{ml}$ compared with the cells received PBS instead (Figure 1). The same is true for the groups pretreated with $5 \mu \mathrm{g} / \mathrm{ml}$ LPS versus PBS controls ( $\alpha$ $<0.05)$. With the increase in LPS dosage, a further increased cell death was observed in those cells which received $1 \mu \mathrm{g} / \mathrm{ml}$ LPS or $5 \mu \mathrm{g} / \mathrm{ml}$ LPS and then were exposed to $1 \%$ or $2 \% \mathrm{H}_{2} \mathrm{O}_{2}$ (Figure 1). For $3 \% \mathrm{H}_{2} \mathrm{O}_{2}$ treatments, no significant difference was observed between the two LPS concentrations, which may be because $\mathrm{H}_{2} \mathrm{O}_{2}$ induced cell death became predominant. Those results suggest that LPS pretreatment synergistically enhances the $\mathrm{H}_{2} \mathrm{O}_{2}$ caused cell death.

\section{LPS induced gene expression changes}

Using multiplex amplification and microarray, we identified $883(78 \%)$ mRNA species with signals significantly higher than backgrounds ( $p<0.05$, Welch's $t$-test) in T98G cells under various conditions (Figure 2). Of the 883 genes, $51(4.5 \%)$ were down-regulated, while 76 $(6.7 \%)$ were up-regulated by different LPS treatments. In the down-regulated group, the expression of 31 out of 51 genes began to decrease significantly $(\alpha<0.05)$ at the lower dose of LPS $(1 \mu \mathrm{g} / \mathrm{ml})$, and the rest also showed significant $(\alpha<0.05)$ down-regulation at higher does LPS (5 $\mu \mathrm{g} / \mathrm{ml})$. In the up-regulated group, 55 out of 76 mRNA species began significantly $(\alpha<0.05)$ to raise in response to the lower dose of LPS $1 \mu \mathrm{g} / \mathrm{ml}$, while 21 increased sig- nificantly $(\alpha<0.05)$ at higher dose of LPS $(5 \mu \mathrm{g} / \mathrm{ml})$ (Figure. 2, Additional file 1$)$.

LPS treatments induced alteration in expression for a wide range of genes in the T98G cells, including those relevant to antioxidant, antibacterial, growth factor, apoptosis, gene transcription, brain function, cytoskeletal rearrangement, astrocytic differentiation, transfer of cargo between intracellular membranes of organelles, cell adhesion, cell cycle regulation, pro-inflammatory cytokines, etc. (Additional file 1).

Amidst the group of genes down regulated by LPS, the ones related to antioxidation were outstanding (Additional file 1). These genes included: (1) glutathione Stransferase A-4 (gsta4), a member of the glutathione Stransferase family, crucially associated with glutathione antioxidantion [26], (2) kinase C-epsilon (prkce) that functions to prevent cell injury from ischemia-reperfusion like insult [27], (3) cytochrome b561 (cyb561) that is a ferric reductase to maintain ferrous-ferric homeostasis in cells [28]. Decreased ferrous/ferric ratio was observed in neuronal degeneration diseases [29], indicating the deficiency in the antioxidant in the affected patients, (4) vasoactive intestinal peptide (VIP) type 1 receptor (vipr1), which is the major type of receptor mediating VIP activity. VIP which was reported to have antioxidant effect on inhibition of INF- $\gamma$ stimulated nicotinamide adenine dinucleotide phosphate (NADPH) oxidative pathways in murine macrophages [30], (5) macrophage stimulating protein (mst1), which is also known as hepatocyte growth factorlike protein, and was reported to inhibit the production of nitric oxide (NO), a reactive oxygen species, in the injured hypoglossal nuclei [31]. In contrast, endothelial nitric oxide synthase (eNOS) is significantly increased after the LPS treatment. The above data imply a decreased antioxidant capacity in the LPS treated astrocytes.

\section{Correlation between down-regulated genes and cell viability after $\mathrm{H}_{2} \mathrm{O}_{2}$ treatment}

As Pearson product-moment correlation coefficient $r>$ $0.988(\alpha<0.05)$ was used as the significance level cutoff, amidst the down-regulated genes, 12 are significantly correlated with cell viability, while only one gene whose expression is significantly correlated with cell viability in the up-regulated group (Table 1).

Interestingly, the $r$ values for cytochrome b561, the ferric reductase, are $0.771,0.963,0.990$, and 0.999 in the groups treated with PBS, $1 \%, 2 \%$ and $3 \% \mathrm{H}_{2} \mathrm{O}_{2}$, respectively (Table 1), indicating a strong intrinsic association of cytochrome b561 gene expression and cell viability. VIP receptor 1 displays an $r$ of 0.995 in the $3 \% \mathrm{H}_{2} \mathrm{O}_{2}$ treated group (Table 1). The other antioxidant genes also had high $r$ values although are not significant. For instance, $r$ 

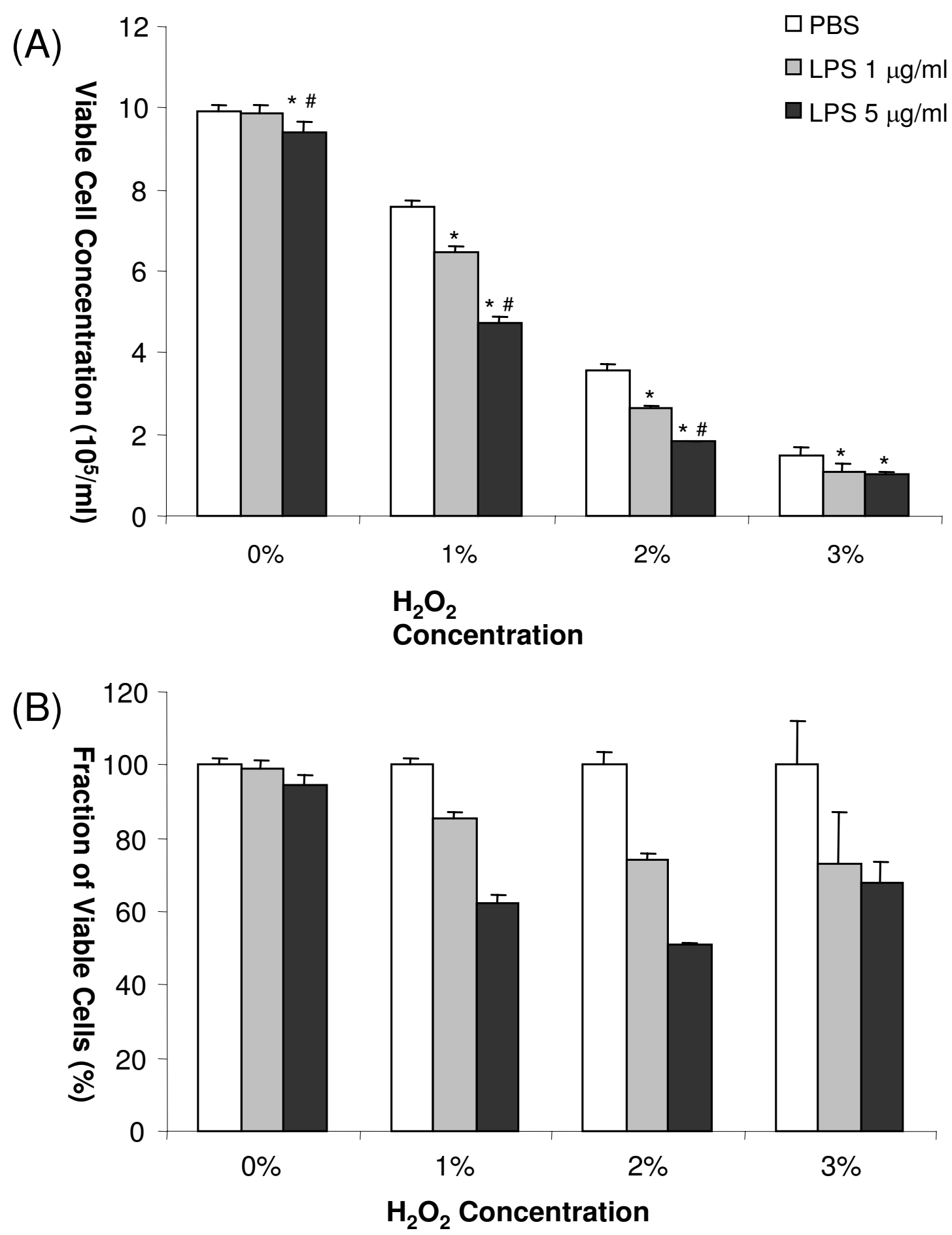

Figure I

Illustration of results from the study of astrocyte death caused by LPS treatment followed by $\mathrm{H}_{2} \mathrm{O}_{2}$ exposure. (A). Effect of LPS and $\mathrm{H}_{2} \mathrm{O}_{2}$ concentration on cell viability. "*" indicates statistically significantly different $(\alpha<0.05)$ from PBS treatment in the same subgroups (the same $\mathrm{H}_{2} \mathrm{O}_{2}$ concentration), and "\#" indicates statistically significantly different $(\alpha<0.05)$ from sample pretreated with I $\mu \mathrm{g} / \mathrm{ml}$ LPS in the same subgroup. Vertical bars represent range of variation of the cell viability error bars indexing the standard deviations (SD) based on three independent experiments. (B). The same set of data in (A) but are presented in percentages of viable cells compared with the PBS controls in the same subgroups. 


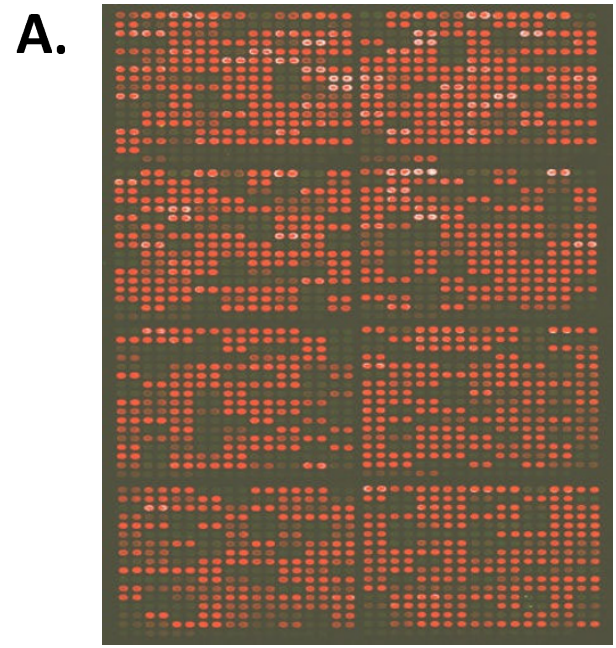

PBS Control

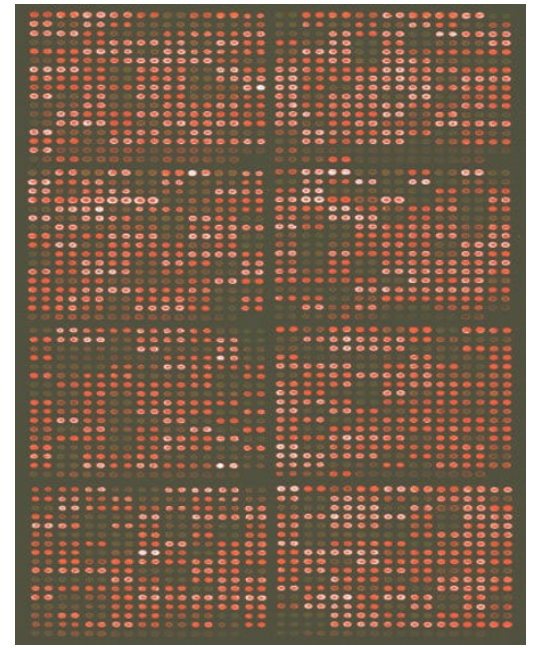

LPS $1 \mu \mathrm{g} / \mathrm{ml}$

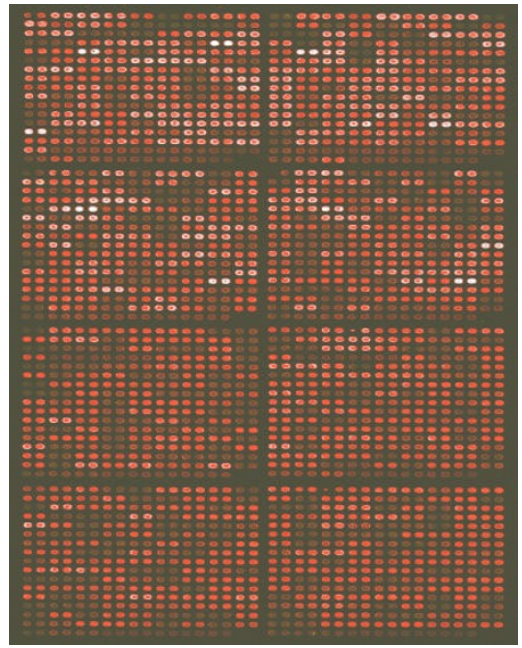

LPS $5 \mu \mathrm{g} / \mathrm{ml}$
B.
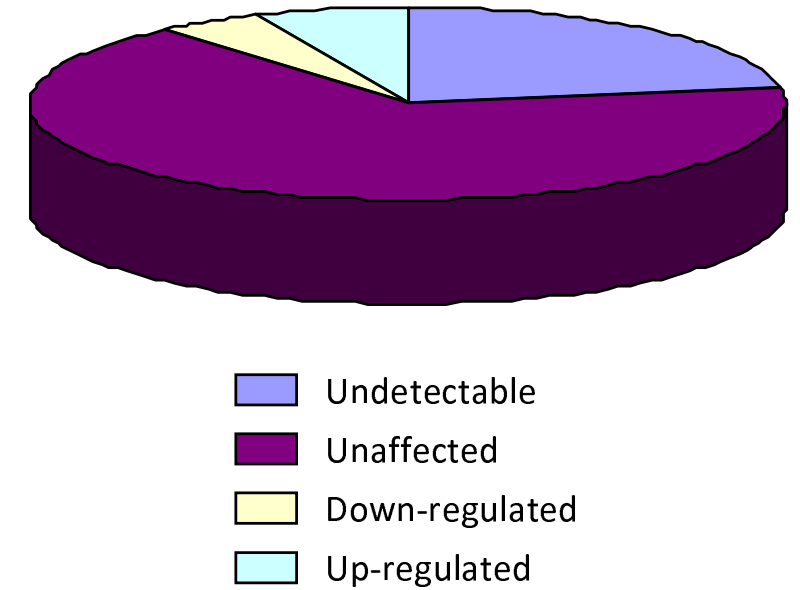

Undetectable

Unaffected

Down-regulated

Up-regulated
C.

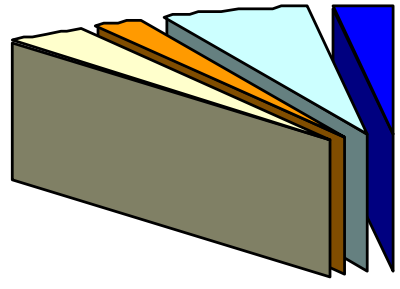

Down regulated under $1 \mu \mathrm{g} / \mathrm{ml}$ LPS

Down regulated under $5 \mu \mathrm{g} / \mathrm{ml}$ LPS

Up regulated under $1 \mu \mathrm{g} / \mathrm{ml}$ LPS

Up regulated under $5 \mu \mathrm{g} / \mathrm{ml}$ LPS

\section{Figure 2}

Illustration of microarray results. In each array, all the I, I35 oligonucleotide probes were spotted twice. (A). Microarray images for PBS control, I and $5 \mu \mathrm{g} / \mathrm{ml}$ LPS treatments; (B) Pie chart presentation of the expression profile of the I I 35 genes. (C) Illustration of the portion of significantly down- and up-regulated genes in the presence of I and $5 \mu \mathrm{g} / \mathrm{ml} \mathrm{LPS}$.

values for $g s t a 4, p r k c$, and $m s t 1$ are $0.967,0.968$, and 0.983 in the $3 \% \mathrm{H}_{2} \mathrm{O}_{2}$ treated groups, respectively (Table 1).

Other impressive genes with their expression highly correlated with cell viability are growth factors, including $c$-fos induced growth factor (figf), growth factor receptorbound protein 2 ( $g r b 2)$, insulin-like growth factor binding protein 2 (igfbp2), v-fos FBJ murine osteosarcoma viral oncogene homolog (fos) and FBJ murine osteosarcoma viral oncogene homolog B (fosb). (Table 1, and Additional file 1). The expression of figf and fos achieved a significant level to correlate with cell viability, while fosb, grb2 and igfbp2 show high, but not significant $r$ values of 0.987 , 0.972 and 0.985 , respectively, in the $3 \% \mathrm{H}_{2} \mathrm{O}_{2}$ group (Table 1). The gene expressions of growth factor receptorbound protein 2 ( $g r b 2)$ and insulin-like growth factor binding protein 2 (igfbp2) also showed high correlation with T98G cell viability (Table 1). The gene products of those two genes are involved in cross-talking of growth factor pathway and other pathways [32-34]. Decline of somatostatin receptor 2 (sstr2) gene expression was reported to be associated with brain cell injury [35]. In the present study, sstr 2 gene expression showed significant correlation with T98G cell viability in $1 \% \mathrm{H}_{2} \mathrm{O}_{2}$ (Table 1). 
Table I: Correlation between gene expression and cell viability

\begin{tabular}{|c|c|c|c|c|c|c|}
\hline \multirow[t]{2}{*}{ Accession Number } & \multirow[t]{2}{*}{ Gene Name } & \multirow[t]{2}{*}{ LPS $(\mu \mathrm{g} / \mathrm{ml})$} & \multicolumn{4}{|c|}{ Pearson Correlation Coefficient $(r)$} \\
\hline & & & Control (PBS) & $\mathbf{I} \% \mathbf{H}_{2} \mathbf{O}_{2}$ & $2 \% \mathrm{H}_{2} \mathbf{O}_{2}$ & $3 \% \mathbf{H}_{2} \mathbf{O}_{2}$ \\
\hline \multicolumn{7}{|l|}{ Down Regulated } \\
\hline \multicolumn{7}{|l|}{ Adhesion } \\
\hline NM 001797 & $\begin{array}{l}\text { cadherin II, type 2, OB-cadherin (osteoblast) } \\
\text { (CDHII) }\end{array}$ & 5 & 0.7715 & 0.9635 & 0.9903 & 0.9993 \\
\hline \multicolumn{7}{|l|}{ Anti-Oxidant } \\
\hline NM 001512 & glutathione S-transferase A4 (GSTA4) & 1 & 0.6140 & 0.8818 & 0.9360 & 0.9669 \\
\hline NM 020998 & macrophage-stimulating protein (MSTI) & I & 0.6693 & 0.9135 & 0.9589 & 0.9827 \\
\hline NM 005400 & protein kinase C, epsilon (PRKCE) & 5 & 0.6189 & 0.8847 & 0.9382 & 0.9684 \\
\hline NM 004624 & vasoactive intestinal peptide receptor I (VIPRI) & 5 & 0.7329 & 0.9462 & 0.9804 & 0.9953 \\
\hline NM 001915 & cytochrome b-56I (CYB56I) & 5 & 0.7711 & 0.9633 & 0.9902 & 0.9992 \\
\hline \multicolumn{7}{|c|}{ Antibacterial Factors } \\
\hline NM 020993 & B-cell CLL/lymphoma 7A (BCL7A) & 1 & 0.8045 & 0.9765 & 0.9963 & 0.9999 \\
\hline NM 001735 & sapiens complement component 5 (C5) & i & 0.5590 & 0.8478 & 0.9100 & 0.9473 \\
\hline NM 000565 & interleukin 6 receptor (IL6R) & 1 & 0.6850 & 0.9220 & 0.9648 & 0.9865 \\
\hline \multicolumn{7}{|l|}{ Apoptosis } \\
\hline NM 000435 & notch homolog 3 (Drosophila) (NOTCH3), & 1 & 0.7489 & 0.9536 & 0.9848 & 0.9973 \\
\hline NM 001618 & $\begin{array}{l}\text { poly (ADP-ribose) polymerase family, member I } \\
\text { (PARPI), }\end{array}$ & 1 & 0.6838 & 0.9214 & 0.9643 & 0.9862 \\
\hline NM_021136 & reticulon I (RTNI) & 1 & 0.6122 & 0.8807 & 0.9352 & 0.9663 \\
\hline NM 000041 & apolipoprotein E (APOE) & 5 & 0.7164 & 0.9381 & 0.9754 & 0.9927 \\
\hline NM 001964 & early growth response I (EGRI) & 5 & 0.7975 & 0.9739 & 0.9952 & 1.0000 \\
\hline \multicolumn{7}{|l|}{ Brain Function } \\
\hline NM 000027 & aspartylglucosaminidase (AGA) & 1 & 0.5997 & 0.8732 & 0.9295 & 0.9621 \\
\hline NM 00044I & solute carrier family 26, member 4 (SLC26A4) & 5 & 0.7566 & 0.9571 & 0.9868 & 0.9981 \\
\hline NM 004283 & RAB3D, member RAS oncogene family (RAB3D) & 5 & 0.8235 & 0.9830 & 0.9986 & 0.9988 \\
\hline NM 003045 & $\begin{array}{l}\text { solute carrier family } 7 \text { (cationic amino acid } \\
\text { transporter, } y+\text { system), member I (SLC7AI) }\end{array}$ & 5 & 0.6901 & 0.9247 & 0.9666 & 0.9876 \\
\hline \multicolumn{7}{|l|}{ Cancer Marker } \\
\hline NM 016730 & folate receptor I (adult) (FOLRI) & 1 & 0.6441 & 0.8994 & 0.9489 & 0.9760 \\
\hline NM 005635 & synovial sarcoma, $X$ breakpoint I (SSXI) & 1 & 0.7612 & 0.9591 & 0.9879 & 0.9985 \\
\hline \multicolumn{7}{|l|}{ Cell Cycle Regulation } \\
\hline NM 005982 & SIX homeobox I (SIXI) & 5 & 0.6397 & 0.8969 & $0.947 \mid$ & 0.9748 \\
\hline NM 005994 & T-box 2 (TBX2) & 5 & 0.6035 & 0.8755 & 0.9312 & 0.9634 \\
\hline \multicolumn{7}{|c|}{ Cytoskeletal Constitution and Rearrangement } \\
\hline NM 001621 & aryl hydrocarbon receptor (AHR) & I & 0.6673 & 0.9124 & 0.9582 & 0.9822 \\
\hline NM 000269 & $\begin{array}{l}\text { non-metastatic cells I, protein (NM23A) expressed } \\
\text { in (NMEI) }\end{array}$ & 1 & 0.5921 & 0.8685 & 0.9260 & 0.9595 \\
\hline NM 003289 & tropomyosin 2 (beta) (TPM2) & 1 & 0.7030 & 0.9314 & 0.9710 & 0.9903 \\
\hline NM 015873 & villin-like (VILL) & 1 & 0.5310 & 0.8296 & 0.8956 & 0.9361 \\
\hline NM 003023 & SH3-domain binding protein 2 (SH3BP2) & 5 & 0.7448 & 0.9517 & 0.9837 & 0.9969 \\
\hline \multicolumn{7}{|c|}{ Extra Cellular Matrix-Degrading Proteases } \\
\hline NM 007038 & $\begin{array}{l}\text { ADAM metallopeptidase with thrombospondin } \\
\text { type I motif, } 5 \text { (aggrecanase-2) (ADAMTS5) }\end{array}$ & I & 0.6070 & 0.8776 & 0.9328 & 0.9646 \\
\hline \multicolumn{7}{|c|}{ Growth Factor and Related Protein Factors } \\
\hline NM 018127 & elaC homolog 2 (E. coli) (ELAC2) & 1 & 0.6819 & 0.9203 & 0.9636 & 0.9858 \\
\hline NM 003506 & frizzled homolog 6 (Drosophila) (FZD6), & 1 & 0.7105 & 0.9352 & 0.9735 & 0.9917 \\
\hline NM 018344 & $\begin{array}{l}\text { solute carrier family } 29 \text { (nucleoside transporters), } \\
\text { member } 3 \text { (SLC29A3) }\end{array}$ & I & 0.6177 & 0.8840 & 0.9376 & 0.9680 \\
\hline NM 021724 & $\begin{array}{l}\text { nuclear receptor subfamily I, group D, member I } \\
\text { (NRIDI) }\end{array}$ & I & 0.6802 & 0.9194 & 0.9630 & 0.9854 \\
\hline NM 001012 & ribosomal protein S8 (RPS8) & 1 & 0.6111 & 0.8801 & 0.9347 & 0.9659 \\
\hline NM 003087 & $\begin{array}{l}\text { synuclein, gamma (breast cancer-specific protein I) } \\
\text { (SNCG) }\end{array}$ & 1 & 0.7776 & 0.9660 & 0.9916 & 0.9996 \\
\hline NM 015906 & tripartite motif-containing 33 (TRIM33), & 1 & 0.7008 & 0.9303 & 0.9703 & 0.9898 \\
\hline NM 000222 & $\begin{array}{l}\text { v-kit Hardy-Zuckerman } 4 \text { feline sarcoma viral } \\
\text { oncogene homolog (KIT) }\end{array}$ & 1 & 0.6613 & 0.9091 & 0.9558 & 0.9807 \\
\hline YI2863 & growth factor FIGF & 5 & 0.7831 & 0.9683 & 0.9927 & 0.9998 \\
\hline NM 002086 & growth factor receptor-bound protein 2 (GRB2) & 1 & 0.6311 & 0.8919 & 0.9434 & 0.9722 \\
\hline
\end{tabular}


Table I: Correlation between gene expression and cell viability (Continued)

\begin{tabular}{|c|c|c|c|c|c|c|}
\hline M354I0 & $\begin{array}{l}\text { insulin-like growth factor binding protein } 2 \\
\text { (IGFBP2) }\end{array}$ & $\mathrm{T}$ & 0.6801 & 0.9194 & 0.9630 & 0.9854 \\
\hline NM 001050 & somatostatin receptor 2 (SSTR2) & I & 0.9252 & 0.9996 & 0.9871 & 0.9658 \\
\hline NM 016135 & ets variant gene 7 (TEL2 oncogene) (ETV7) & 5 & 0.6810 & 0.9198 & 0.9633 & 0.9856 \\
\hline NM 006732 & $\begin{array}{l}\text { FBJ murine osteosarcoma viral oncogene homolog } \\
\text { B (FOSB) }\end{array}$ & 5 & 0.6889 & 0.9240 & 0.9662 & 0.9873 \\
\hline NM 022963 & fibroblast growth factor receptor 4 (FGFR4) & 5 & 0.6720 & 0.9150 & 0.9600 & 0.9834 \\
\hline NM 002957 & retinoid $\times$ receptor, alpha $(\mathrm{RXRA})$ & 5 & 0.9264 & 0.9995 & 0.9866 & 0.9650 \\
\hline NM 004630 & splicing factor I (SFI) & 5 & 0.8712 & 0.9955 & 0.9993 & 0.9904 \\
\hline NM 005252 & $\begin{array}{l}\text { v-fos FBJ murine osteosarcoma viral oncogene } \\
\text { homolog (FOS) }\end{array}$ & 5 & 0.8257 & 0.9837 & 0.9988 & 0.9986 \\
\hline \multicolumn{7}{|l|}{ Hemostasis } \\
\hline NM 000624 & $\begin{array}{l}\text { peptidase inhibitor, clade A (alpha-I antiproteinase, } \\
\text { antitrypsin), member } 5 \text { (SERPINA5) }\end{array}$ & I & 0.6092 & 0.8790 & 0.9339 & 0.9653 \\
\hline \multicolumn{7}{|c|}{ Inflammation and Immunity } \\
\hline NM 000963 & cyclooxygenase-2 (COX2) & I & 0.5186 & 0.8213 & 0.8890 & 0.9308 \\
\hline \multicolumn{7}{|c|}{ Transfer of Cargo Between Intracellular Membrane Organelles } \\
\hline NM 016577 & RAB6B, member RAS oncogene family (RAB6B) & I & 0.7002 & 0.9299 & 0.9701 & 0.9897 \\
\hline \multicolumn{7}{|l|}{$\begin{array}{l}\text { Up Regulated } \\
\text { Cancer Marker }\end{array}$} \\
\hline NM 005814 & glycoprotein A33 (transmembrane) (GPA33) & I & -0.9658 & -0.9878 & -0.9589 & -0.9251 \\
\hline \multicolumn{7}{|l|}{ Cell Junction } \\
\hline NM 001943 & desmoglein 2 (DSG2) & I & -0.6663 & -0.9119 & -0.9578 & -0.9820 \\
\hline \multicolumn{7}{|c|}{ Cytoskeletal Constitution and Rearrangement } \\
\hline NM 002613 & $\begin{array}{l}\text { 3-phosphoinositide dependent protein kinase-I } \\
\text { (PDPKI) }\end{array}$ & I & -0.5869 & -0.8653 & -0.9235 & -0.9577 \\
\hline \multicolumn{7}{|c|}{ Gene Transcription } \\
\hline NM 006180 & $\begin{array}{l}\text { neurotrophic tyrosine kinase receptor, type } 2 \\
\text { (NTRK2) }\end{array}$ & I & -0.6822 & -0.9205 & -0.9637 & -0.9858 \\
\hline NM 013275 & $\begin{array}{l}\text { nasopharyngeal carcinoma susceptibility protein; } \\
\text { |z|6/ankyrin repeat domain II (ANKRDII) }\end{array}$ & I & -0.7789 & -0.9666 & -0.9918 & -0.9997 \\
\hline
\end{tabular}

*Genes with a Pearson's product-moment correlation coefficient $\left(r^{2}\right)>0.85$ are listed. Those with coefficient $r>0.988(\alpha<0.05)$ are in bold face.

Nerve growth factor was detected in the present study, but its gene expression appeared not to be affected by LPS treatment (Table 2), implying nerve growth factor may not be involved in causing astrocyte death in sepsis at the gene expression level.

The present study indicates that astrocytes may not be the major source to release chemotactic factors, and therefore, they may not actively recruit monocytes and neutrophils to the site under LPS treatment. Our results indicate that gene expression of $i l 1 b$, il 6 and il12 were suppressed by LPS, while mRNAs of il2, il3, il4, il5, il9 and il13 were not detectable in T98G cells (Table 2). il11 expression was increased by LPS treatment (Table 2), which is consistent to the notion that $i l 11$ is expressed in astrocytes under inflammatory stimuli [36]. Interestingly, the ill1 generated by astrocytes in response to inflammation may have a protective function for survival of oligodendroglia that myolinated the axons of neurons [36]. The LPS induced il11 gene expression may reflect a cell protective mechanism in sepsis.

Several tumor necrosis factor ( $t n f)$ family members were included in the present study. Gene expression of $\operatorname{tnf} \alpha$, the most studied cytokine involved in inflammation and cell death, was not detectable in T98G cells, while gene expression of its receptors, $\operatorname{tnfr} 1$ and $t n f r 2$ were unaffected by the LPS treatment, indicating cell death induced in the present study was independent of gene expressions of tnf $\alpha, t n f r 1$ and $t n f r 2$ of T98G (Table 2). Gene expression of TNF ligand superfamily member 14 (tnfsf14) was increased as the LPS dose increased, but did not show meaningful correlation with the cell viability (Table 2). TNFSF14 which is a homolog of lymphotoxin was reported to inhibit tumor growth [37]. Considering the cancerous nature of T98G cell, LPS induced $\operatorname{tnfs} s 14$ expression may imply brain tumor suppression function in some cases [38]. Conspicuously, cyclooxygenase $2(\cos 2)$ gene expression was significantly suppressed by LPS pretreatment (Table 1, and Additional file 1), though the suppression level was not significantly correlated with cell viability. The gene of cox2 is broadly expressed in cancers and is suggested to be a potent enzyme in arachidonic acid metabolism to favor the tumor growing [39]. Our results are in consistent with the anticancerous effect of LPS [38].

With the undetectable or unaffected mRNAs of TNFa and its receptors under LPS treatment, caspase 8 and caspase 10 , the key factors to mediate apoptotic signals from the 
Table 2: Genes associated with cytokines, cell death, and growth

\begin{tabular}{|c|c|c|}
\hline Accession Number & Gene Name & mRNA* \\
\hline \multicolumn{3}{|l|}{ Interleukins } \\
\hline NM 000576 & interleukin beta; ill b & U/A \\
\hline MI4584 & interleukin 6 (interferon; beta 2); IL-6 & U/A \\
\hline NM 000882 & interleukin I2a; il I $2 \mathrm{a}$ & U/A \\
\hline NM 000641 & interleukin II; ill I & Up \\
\hline NM 000640 & interleukin 13 receptor alpha 2 ; il 3 ra2 & $U_{p}$ \\
\hline NM 000565 & interleukin 6 receptor; IL-6Ra & Down \\
\hline NM 000586 & interleukin 2; il2 & $U / D$ \\
\hline NM 000588 & interleukin 3 colony-stimulating factor multiple; il3 & $U / D$ \\
\hline NM 000589 & interleukin 4; il4 & $U / D$ \\
\hline NM 000879 & interleukin 5 colony-stimulating factor eosinophil; il5 & $\mathrm{U} / \mathrm{D}$ \\
\hline NM 000590 & interleukin 9; il9 & $\mathrm{U} / \mathrm{D}$ \\
\hline NM 002188 & interleukin 13; ill3 & $\mathrm{U} / \mathrm{D}$ \\
\hline NM 001562 & interleukin I8; ill8 & $\mathrm{U} / \mathrm{D}$ \\
\hline \multicolumn{3}{|c|}{ Tumor Necrosis Factors } \\
\hline NM 003807 & tumor necrosis factor ligand superfamily member 14 ; tnfsf 14 & Up \\
\hline NM 001065 & tumor necrosis factor receptor $55 \mathrm{kd}$; tnfrsfla & $U / A$ \\
\hline NM 001066 & tumor necrosis factor receptor $275 \mathrm{kd}$; tnfrsflb & U/A \\
\hline NM 006291 & tumor necrosis factor alpha-induced protein 2; tnfaip2 & $\mathrm{U} / \mathrm{A}$ \\
\hline NM 032945 & tumor necrosis factor receptor superfamily member $6 \mathrm{~b}$ precursor isoform d; tnfrsf6b & $\mathrm{U} / \mathrm{A}$ \\
\hline NM 003811 & tumor necrosis factor ligand superfamily member 9; tnfsf 9 & U/A \\
\hline NM 003810 & tumor necrosis factor ligand superfamily member 10 ; tnfsf 10 & U/A \\
\hline NM 003842 & tumor necrosis factor receptor superfamily member $10 \mathrm{~b}$; tnfrsf $\mathrm{I} 0 \mathrm{~b}$ & U/A \\
\hline NM 006573 & tumor necrosis factor ligand superfamily member I3b; tnfsf $13 \mathrm{~b}$ & $\mathrm{U} / \mathrm{A}$ \\
\hline NM 003820 & tumor necrosis factor receptor superfamily member 14 ; herpesvirus entry mediator; tnfrsf $\mid 4$ & U/A \\
\hline NM 000594 & tumor necrosis factor cachectin (TNF) & $U / D$ \\
\hline NM 001244 & tumor necrosis factor ligand superfamily member 8 ; tnfsf8 & $\mathrm{U} / \mathrm{D}$ \\
\hline NM 003844 & tumor necrosis factor receptor superfamily member $10 \mathrm{a}$; tnfrsf $\mathrm{IOa}$ & $\mathrm{U} / \mathrm{D}$ \\
\hline \multicolumn{3}{|c|}{ 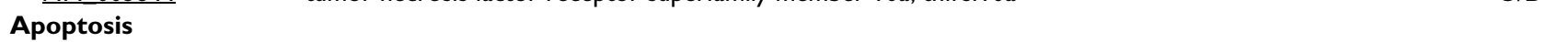 } \\
\hline$\underline{\mathrm{U} 82987}$ & Bcl-2 binding component 3 (bbc3) & Up \\
\hline NM 003879 & casp8 and fadd-like apoptosis regulator; cflar & U/A \\
\hline NM 032977 & caspase 10 isoform d small subunit; casp 10 & U/A \\
\hline NM 033356 & caspase 8 isoform c; casp8 & $\mathrm{U} / \mathrm{A}$ \\
\hline NM 000043 & apoptosis apo-I antigen I; tnfrsf6 & $\mathrm{U} / \mathrm{A}$ \\
\hline NM 001160 & apoptotic protease activating factor isoform b; apafl & U/A \\
\hline$\underline{\mathrm{U} 59747}$ & BCL2-like 2; Bcl-w & U/A \\
\hline NM 032989 & bcl2-antagonist of cell death protein; bad & U/A \\
\hline AF022224 & Bcl-2-associated athanogene; BAG-I & $\mathrm{U} / \mathrm{A}$ \\
\hline NM 003766 & beclin coiled-coil myosin-like bcl2-interacting protein; becn I & $\mathrm{U} / \mathrm{A}$ \\
\hline NM 000639 & apoptosis apo-I antigen ligand I; tnfsf6 & $U / D$ \\
\hline NM 021631 & apoptosis inhibitor; fksg2 & $U / D$ \\
\hline NM 004874 & bcl2-associated athanogene 4 ; bag4 & $U / D$ \\
\hline \multicolumn{3}{|c|}{ Nerve Growth Factors } \\
\hline NM 002507 & nerve growth factor receptor; ngfr & U/A \\
\hline$\times 52599$ & nerver growth factor; beta polypeptide; NGF & $\mathrm{U} / \mathrm{A}$ \\
\hline
\end{tabular}

*U/A, unaffected. U/D, undetectable

TNF family [40], was also unaffected by the LPS in their gene expression (Table 2). Bcl-2 family plays crucial roles in pro- or anti-apoptosis [41]. Neither mRNA of Bcl-w, a factor functioning in blocking apoptosis, nor mRNA of $\mathrm{Bad}$, the factor playing an opposite role as to $\mathrm{Bcl}-\mathrm{w}$, was affected by LPS (Table 2). Markedly, gene expression of $B c l-2$ binding component 3 (bbc3), a strong pro-apoptotic factor, was induced by LPS (Table 1,2 ). The $b b c 3$ gene is a direct target of $\mathrm{p} 53$ and is also induced by p53 independ- ent apoptotic stimuli such as dexamethason treatment and serum deprivation [42]. Interestingly, its expression could be suppressed by growth factors [42], which may coordinate the growth factor suppression in the present study. The $b b c 3$ gene expression does not show a correlation with the cell death, indicating the possibility of multiple regulation levels involved in the cell death resulted from LPS coupled with $\mathrm{H}_{2} \mathrm{O}_{2}$ treatment. 


\section{Discussion}

Our results showed that LPS itself was insufficient to cause T98G cell death. However, when subsequently treated with $\mathrm{H}_{2} \mathrm{O}_{2}$, the LPS effect in inducing cell death could be significantly enhanced, which might be underlain by altered gene expression through pre-exposure of LPS. In systemic sepsis, LPS first accesses the endothelial layer of the blood-brain barrier. In addition to cell death leading to compromise integrity of endothelial layer in the bloodbrain barrier, the permeability of the vascular barrier can also be changed in response to LPS via paracelluar permeability. The paracellular pathway is composed of both tight junctions and adherens junctions between endothelial cells. These inter-endothelial junctions are compromised under LPS stimulation and leaky to liquid and solutes [43]. In this case, astrosytes are exposed to LPS directly.

LPS treatment suppressed expression of antioxidant genes such as cyb561, gsta4, prkce, mst1 and vipr1 (Table 1, and Additional file 1). Suppression of antioxidant gene expression subjects the cells to increased oxidative stress. When this happens in astrocytes, LPS may simultaneously stimulate neighboring cells, i.e., endothelial cells to release chemotactic factors such as TNF $\alpha$, IL-1 $\beta$, INF- $\gamma$ to attract monocytes and nerutrophils to the niche. Subsequently, monocytes and neutrophils are triggered by LPS and proinflammatory cytokines to generate $\mathrm{H}_{2} \mathrm{O}_{2}$. In the brain, microglial cells are the member of the monocyte/ macrophage family and it may be activated by LPS to generate $\mathrm{H}_{2} \mathrm{O}_{2}$ in order to destroy invading bacteria but may cause injury to brain tissues as well [44]. The coexistence of microglia may explain LPS induced cell death in cultured brain slices and in freshly isolated white matter glial cells $[12,13]$.

Cyt b561, GSTA4 and PRKCE are not directly associated with NO pathways, though an increase in NO generation was observed under LPS stimulation in macrophage/ monocyte [45], neutrophil [46] and even astrocyte $[47,48]$ via inducible nitric oxide synthase (iNOS). LPS as an exogenous inducing factor to iNOS has long been established. Therefore, iNOS was not included in the present study. The scavenging of $\mathrm{H}_{2} \mathrm{O}_{2}$ may reduce the tissue level of superoxide $\left(\mathrm{O}_{2}\right)$ on a stoichiometric basis because it is produced from $\mathrm{O}_{2}$. catalyzed by superoxide dismutase. It is plausible that a reduction of tissue $\mathrm{O}_{2} \cdot$ may reduce the production of peroxinitrite that is produced by interaction of $\mathrm{O}_{2}$ and $\mathrm{NO}$ and is a major toxic metabolite of NO causing cell injury [49]. Moreover, MST1 is known to inhibit the production of NO [31]. Its gene expression is also down regulated by the LPS with an $r$ value of 0.98 correlated with cell death in the present study, indicating that a weakened defensiveness to NO and its toxic metabolites may also occur in astrocyte under LPS stress.
Furthermore, the present study showed that LPS suppressed gene expression of growth factors and associated factors. Among the suppressed genes, gene product of figf was reported to be a survival factor in human cell lines by increasing Bcl-2 expression, decreasing caspase activities and inhibition of poly(ADP-ribose) polymerase cleavage to resist hypoxia and chemical induced cell death [50]. fos is a cellular proto-oncogene belonging to the immediate early gene family of transcription factors in response to growth factor and other stimuli [51]. The fos gene family is comprised of four members: fos, fosb, fosl1, and fosl2, which encode leucine zipper proteins that can dimerize with proteins of the JUN family, thereby forming the transcription factor complex AP-1, regulating cell proliferation, differentiation, and transformation [52]. FosB encoded by fos $b$ acts as a regulator in cell proliferation, differentiation, and transformation [51]. GRB2 is a plasma protein involved in mediating growth factor signals via promoting growth factor induced growth-receptor endocytosis [53] and interacting with Ras as well as p21-activated kinase 1 (PAK1) to weave the growth factor pathways [33,34]. IGFBP2 was reported to play a key role in driving glioma cell growth via activation of the Akt pathway and to collaborate with K-Ras or platelet-derived growth factor $\beta$ in the development and progression of glioma [32]. In consistent with the previous studies that expression of sstr2 declined in brain cells in rat trauma model and was associated with brain cell injury [35], the sstr2 gene expression displayed significant correlation with cell viability in $1 \% \mathrm{H}_{2} \mathrm{O}_{2}$ in our present study (Table 1). Since sstr 2 was reported to have neuroprotective potential [35], suppression of sstr 2 gene expression may also contribute to astrocyte death in the present study.

The present study outlines a rational profile on the possible mechanisms that LPS compromises the blood-brain barrier during sepsis. Suppression of antioxidant gene expression of $c y b 561$, gsta4, and prkce indicates a reduction of cell antioxidative capacity. Furthermore, the co-suppression of growth factors and related factors such as figf, fos, fosb, grb2 and igfbp2 may further weaken the cell survival ability to resist harsh stress such as that caused by $\mathrm{H}_{2} \mathrm{O}_{2}$. Growth factors are involved in broad functions in maintaining cell survive. In addition to regulate $\mathrm{Bcl}-2$ and caspase activities, and inhibition of poly(ADP-ribose) polymerase cleavage [50], growth factor may also promote glutathione redox cycling. For instance, nerve growth factor has potent effect to resist $\mathrm{H}_{2} \mathrm{O}_{2}$ damage on neurons via a rapid activation of glutathione redox cycling [54], indicating the direct effect of growth factor to protect cells from reactive oxygen species. Interestingly, in the present study, gene expression of nerve growth factor was not affected by LPS (Table 2), indicating gene expression of nerve growth factor may not be an LPS target to induce the astrocyte death. 


\section{Conclusion}

The facts of LPS suppression of genes encoding antioxidant factors and growth factors, and $\mathrm{H}_{2} \mathrm{O}_{2}$ enhancement of the LPS pretreated cell death suggest a possible crucial mechanism causing blood-brain barrier damage in sepsis and at least in part explains the previously described discrepancy why LPS cause brain cell injury in vivo or in organ culture, but not remarkable with culture astrocytes. When LPS is systemically administered, monocytes and neutrophils may be recruited into the inflammatory niche. These cells may subsequently, generate $\mathrm{H}_{2} \mathrm{O}_{2}$ to trigger cell death. In brain slice organ culture, in addition to the possibly remaining monocytes and macrophages, microglial cells could be the principal source to generate reactive oxygen species in the presence of LPS [55]. These results may shed light on the therapeutic strategies in septic shock patients, though further studies including in vivo studies are needed to define the detailed pathways as well as regulations at the translation and protein-function levels in mediation of astrocyte death.

\section{Methods}

\section{Cell culture, and LPS and $\mathrm{H}_{2} \mathrm{O}_{2}$ treatments}

T98G was purchased from American Type Culture Collection (Manassas, VA). The cell line was maintained in Ham's F-10/DMEM (10:1) medium supplemented with $10 \%$ fetal bovine serum, 100 units $/ \mathrm{ml}$ penicillin, and 100 $\mu \mathrm{g} / \mathrm{ml}$ streptomycin at $37^{\circ} \mathrm{C}$ in a humidified atmosphere containing $5 \% \mathrm{CO}_{2} / 95 \%$ air. When $80 \%$ confluence was achieved, LPS (Salmonella enteriditis, Sigma-Aldrich) was added to the final concentrations of 1 and $5 \mu \mathrm{g} / \mathrm{ml}$, respectively. The controls received equal volumes of PBS instead. After 24-hr treatment with LPS, cells were washed with PBS for three times. Serum free media were added into the cell cultures. Thirty percent of $\mathrm{H}_{2} \mathrm{O}_{2}$ was then added into cell cultures to final concentrations of $1 \%, 2 \%$ and $3 \%$, respectively. Control groups received PBS with no $\mathrm{H}_{2} \mathrm{O}_{2}$ instead. After one hour exposure, $\mathrm{H}_{2} \mathrm{O}_{2}$ was washed away with PBS for three times. Cells were re-cultured in regular media for extra $24 \mathrm{hrs}$. Cell viability was measured with MTT assay as instructed by the vender (Promega). Data were obtained from three independent experiments.

\section{Primer and probe design}

Our recently developed highly sensitive and specific system for high-throughput gene expression profiling was employed [56-58] to study the gene expression profiles in the T98G cells under different experimental conditions. Compared with many conventional methods, the major advantage of this technology is its ability to detect mRNA and to amplify cDNA without using poly-A tails. This system is especially advantageous for the present study since missing Poly-A tails is a remarkable feature in brain mRNA. Our system uses specially designed primer pairs crossing introns for multiplex PCR to make the amplification highly specific. The detection specificity is further guaranteed by using an oligonucleotide probes consisting of sequences in two neighboring exons for microarray detection. With a special primer selection strategy, over 1,000 mRNA species can be detected by a single assay [56,58].

A panel of 1,135 mRNA species relevant to inflammation, cell growth, differentiation, apoptosis, gene expression, antioxidant, etc. was amplified simultaneously using our high-throughput system. For each dose of LPS treatment and the PBS control, data were obtained from two separate cell cultures of the same cell line, T98G. Each culture was analyzed with duplicated microarrays. In each array, all oligonucleotide probes were spotted twice. Therefore, each treatment was totally repeated eight times. For each array, 57 mismatch probes were selected from human genome as hybridization controls, which showed no interaction with the genes for testing.

The two conventional housekeeping gene controls, glyceraldehyde-3-phosphate dehydrogenase (GAPDH) and $\beta$ actin were used as controls in the present study. Endothelial nitric oxide synthase 3 (NOS3) was used as an additional control since both GAPDH and $\beta$-actin gene share significant sequence identity with many pseudogenes. NOS3 is constitutively expressed and may be inducible in the brain. It has been known that it has no splicing alternative and pseudogene.

\section{One-Step RT-PCR}

For One-Step RT-PCR, 200 T98G cells were used after cell lysis with a freezing and thawing procedure [56-58]. Briefly, cells in the lysis buffer $\left(1.5 \mu \mathrm{l}\right.$ RNasin ${ }^{\circledast}$ Ribonuclease inhibitor, $2 \mu \mathrm{l}$ of $5 \times$ QIAGEN OneStep RT-PCR buffer, $5.5 \mu \mathrm{H}_{2} \mathrm{O}$ ) were lysed with three repeating cycles of alternating one-min incubation between an ethanol/dry ice mix and a $37^{\circ} \mathrm{C}$ water bath. One-step RT-PCR was carried out in a $50-\mu \mathrm{l}$ reaction containing primers (20 nM each) for all the 1,135 mRNA species, $2.5 \mathrm{mM} \mathrm{MgCl}_{2}$, the four dNTPs (400 $\mu \mathrm{M}$ each), 5 units of RNasin ${ }^{\circledast}$ Ribonuclease Inhibitor (Promega) and 2.0 $\mu$ l QIAGEN OneStep RT-PCR Enzyme Mix. The samples were first treated at $50^{\circ} \mathrm{C}$ for 40 min to synthesize the selected cDNAs, and then were heated to $95^{\circ} \mathrm{C}$ for $15 \mathrm{~min}$ to inactivate the reverse transcriptase and activate the Taq DNA polymerase followed by 35 PCR cycles. Each PCR cycle consisted of $40 \mathrm{sec}$ at $94^{\circ} \mathrm{C}$ for denaturation, and $1 \mathrm{~min}$ at $50^{\circ} \mathrm{C}$ for annealing and $5 \mathrm{~min}$ of ramping from $50^{\circ} \mathrm{C}$ to $70^{\circ} \mathrm{C}$ for annealing and extension. At the end of the PCR, a final extension step was carried out at $72^{\circ} \mathrm{C}$ for $3 \mathrm{~min}$. All PCRs were performed with the PTC100 Programmable Thermal Controllers (MJ Research). Single-stranded DNA (ssDNA) was generated by using the same conditions in the multiplex 
PCR step except for the templates that were $2 \mu$ of the multiplex RT-PCR product. Only one primer for each sequence was used, and 50 thermal cycles were carried out.

\section{Microarray hybridization and probe labeling}

Hybridization was performed in $30 \mu \mathrm{l}$ of $1 \times$ hybridization solution ( $5 \times$ Denhart's solution, $0.5 \%$ SDS, $3 \times$ SSC, $20 \mu \mathrm{l}$ of ssDNA at $56^{\circ} \mathrm{C}$ for $2 \mathrm{hrs}$. The slide was then washed with $1 \times$ SSC and $0.1 \%$ SDS at $56^{\circ} \mathrm{C}$ for $10 \mathrm{~min}$, rinsed twice with $0.5 \times$ SSC for $30 \mathrm{sec}$ and twice with $0.2 \times$ SSC for $30 \mathrm{sec}$. Microarrays were covered with $25 \mu \mathrm{l} 1 \times$ labeling solution containing 20 units of Sequenase, $1 \times$ Sequenase buffer (GE Healthcare Life Sciences), and $750 \mathrm{nM}$ Cy5-ddCTP (Applied Biosystems). The labeling reaction was performed at $70^{\circ} \mathrm{C}$ for $10 \mathrm{~min}$. The slide was washed again under the same conditions used after hybridization.

\section{Microarray scan}

Microarrays were scanned with a GenePix 4000 scanner (Axon Instruments, Foster City, CA). The resultant images were digitized with the accompanying software GenePix Pro (version 4.0). Cross-array normalization was performed using the linear method described by Hansson et al., [59].

\section{Data analysis}

Signal intensity of each spot was transformed into its natural logarithm. The two-sample $t$-test, Welch's $t$-test, which was considered as an appropriate test for analyzing microarray data [60] was used in the present study. Normalized intensities of each gene were compared to the intensities of the mismatch probes as described by Bonaventure et al. [61]. A gene is considered expressed if its signal intensity is significantly greater than controls with a $p$-value $<0.05$ to reject the null hypothesis in all three treatments including PBS, $1 \mu \mathrm{g} / \mathrm{ml}$ and $5 \mu \mathrm{g} / \mathrm{ml}$ LPS treatments.

The One-way ANOVA followed by Bonferroni Correction Test was used to determine the gene expression changes in response to the LPS treatments. For each mRNA species the above three treatments were compared. A gene was considered as down regulated if the means of signal densities of these three treatments were in an order of PBS $>1$ $\mu \mathrm{g} / \mathrm{ml} \mathrm{LPS}>5 \mu \mathrm{g} / \mathrm{ml}$ LBS, and at least one of the comparisons between the three treatments reached a significance level of $\alpha<0.05$ in the One-Way ANOVA Test followed by Bonferroni Correction Test. If the results were in a reversed order, the gene was considered as up-regulated. The effect of gene expression levels on cell viability was also studied. For each gene, the gene expression levels of the three treatments were compared with cell viabilities in pair with corresponding groups, i.e. the gene expression level of the group treated with $1 \mu \mathrm{g} / \mathrm{ml}$ LPS was paired with the cell viability of the group received $1 \mu \mathrm{g} / \mathrm{LPS}$ treatment and so on. The relationship between those two variables, gene expression level and cell viability, were examined by the Pearson's Correlation. Pearson productmoment correlation coefficient $r>0.988(\alpha<0.05)$ was used as an index for determining whether gene expression has effect on cell viability. In the gene expression downregulated group, decreased cell viability indicated a positive correlation. Vice versa, a negative correlation was ascertained if decreased cell viability was observed in the up-regulated group.

\section{Authors' contributions}

GY conceived of the study, carried out data collection and analysis, and made major effort in manuscript preparation. GS collected and analyzed the T98G cell viability and other data, and conceived of critical ideas for the study. MA developed computer programs for data analysis. QY and GH designed the high-throughput gene expression profiling panel and made microarrays. GH also did microarray data extraction. ML helped to initiate the study. KY and RN conceived of idea for project initiation and other intellectual interaction during the study, and manuscript preparation. DF conceived ideas about the experimental design and data analysis. JY carried out T98 cell culture and treatment. HL conceived of the idea of the highthroughput gene expression profiling experimental scheme, manuscript preparation, and oversaw the study. All authors read and approved the final manuscript.

\section{Additional material}

\section{Additional file 1}

The 127 genes with altered gene expression in the T98G cells after treatment with LPS. The 127 genes that were up and down regulated in the T98G cells after LPS treatment.

Click here for file

[http://www.biomedcentral.com/content/supplementary/14712164-9-608-S1.xls]

\section{Acknowledgements}

Authors thank Dr. Renping Zhou for his support in test of hydrogen peroxide toxicity on T98G. Authors also thank Dr. Hongyuan Shi and Ms. Sheeny Behmard for their help in the data analysis. This work was supported in part by a grant R2 I/R3 I CA96309 from the National Cancer Institute, National Institutes of Health to HL.

\section{References}

I. Martin GS, Mannino DM, Eaton S, Moss M: The epidemiology of sepsis in the United States from 1979 through 2000. N Engl J Med 2003, 348( I6): 1546-1554.

2. Poll $T$ van der, Opal SM: Host-pathogen interactions in sepsis. Lancet Infect Dis 2008, 8(I):32-43.

3. Riedemann NC, Guo RF, Ward PA: The enigma of sepsis. J Clin Invest 2003, I I 2(4):460-467. 
4. Sharshar T, Annane D, de la Grandmaison GL, Brouland JP, Hopkinson NS, Francoise G: The neuropathology of septic shock. Brain Pathol 2004, I 4(I):2I-33.

5. Sharshar T, Gray F, Poron F, Raphael JC, Gajdos P, Annane D: Multifocal necrotizing leukoencephalopathy in septic shock. Crit Care Med 2002, 30( I 0):237|-2375

6. Bohatschek M, Werner A, Raivich G: Systemic LPS injection leads to granulocyte influx into normal and injured brain: effects of ICAM-I deficiency. Exp Neurol 200I, I 72(I):I37-I52.

7. Talvik R, Liigant A, Tapfer H, Tamme K, Metsvaht T: Septic shock with disseminated microfoci in multiple organs in humans. Intensive Care Med 1998, 24(1):73-76.

8. Sharshar T, Gray F, Lorin de la Grandmaison G, Hopkinson NS, Ross E, Dorandeu A, Orlikowski D, Raphael JC, Gajdos P, Annane D: Apoptosis of neurons in cardiovascular autonomic centres triggered by inducible nitric oxide synthase after death from septic shock. Lancet 2003, 362(9398): I799-I805.

9. Frey EA, Finlay BB: Lipopolysaccharide induces apoptosis in a bovine endothelial cell line via a soluble CDI 4 dependent pathway. Microb Pathog 1998, 24(2): I0I-109.

10. Hu X, Yee E, Harlan JM, Wong F, Karsan A: Lipopolysaccharide induces the antiapoptotic molecules, AI and A20, in microvascular endothelial cells. Blood 1998, 92(8):2759-2765.

II. Sharshar T, Hopkinson NS, Orlikowski D, Annane D: Science review: The brain in sepsis - culprit and victim. Crit Care 2005 9(I):37-44.

12. de Bock F, Derijard B, Dornand J, Bockaert J, Rondouin G: The neuronal death induced by endotoxic shock but not that induced by excitatory amino acids requires TNF-alpha. Eur J Neurosci |998, I 0( I 0):3107-31|4.

13. Sherwin C, Fern R: Acute lipopolysaccharide-mediated injury in neonatal white matter glia: role of TNF-alpha, IL-I beta, and calcium. J Immunol 2005, I 75(I): I55- I6I

14. Ji KA, Eu MY, Kang SH, Gwag BJ, Jou I, Joe EH: Differential neutrophil infiltration contributes to regional differences in brain inflammation in the substantia nigra pars compacta and cortex. Glia 2008, 56(I0): 1039-1047.

15. Oikawa M, Ohnami Y, Koike M, Park CH, Oyamada T: Endotoxininduced injury of the central, autonomic and enteric nervous systems and intestinal muscularis in Thoroughbred horses. J Comp Pathol 2007, I36(2-3): I27-132.

16. Damico RL, Chesley A, Johnston L, Bind EP, Amaro E, Nijmeh J, Karakas B, Welsh L, Pearse DB, Garcia JG, Crow MT: Macrophage migration inhibitory factor governs endothelial cell sensitivity to LPS-induced apoptosis. Am J Respir Cell Mol Biol 2008 , 39(I):77-85

17. Wang HL, Akinci IO, Baker CM, Urich D, Bellmeyer A, Jain M, Chandel NS, Mutlu GM, Budinger GR: The intrinsic apoptotic pathway is required for lipopolysaccharide-induced lung endothelial cell death. J Immunol 2007, I79(3):|834-|84I.

18. Chong YH, Lee MJ: Expression of complement inhibitor protein CD59 in human neuronal and glial cell lines treated with HIV-I gp4 I peptides. J Neurovirol 2000, 6( I):5 I-60.

19. Rattan R, Giri S, Singh AK, Singh I: Rho A negatively regulates cytokine-mediated inducible nitric oxide synthase expression in brain-derived transformed cell lines: negative regulation of IKKalpha. Free Radic Biol Med 2003, 35(9): I037-I050.

20. Choi J, Kim WK: Potentiated glucose deprivation-induced death of astrocytes after induction of iNOS. I Neurosci Res 1998, 54(6):870-875.

21. Suk K, Lee J, Hur J, Kim YS, Lee M, Cha S, Yeou Kim S, Kim H: Activation-induced cell death of rat astrocytes. Brain Res 2001 900(2):342-347.

22. Bignami A, Eng LF, Dahl D, Uyeda CT: Localization of the glial fibrillary acidic protein in astrocytes by immunofluorescence. Brain Res 1972, 43(2):429-435.

23. de Joannon AC, Mancini F, Landolfi C, Soldo L, Leta A, Ruggieri A Mangano G, Polenzani L, Pinza M, Milanese C: Adenosine triphosphate affects interleukin - Ibeta release by T98G glioblastoma cells through a purinoceptor-independent mechanism. Neurosci Lett 2000, 285(3):218-222.

24. Gasque P, Chan P, Mauger C, Schouft MT, Singhrao S, Dierich MP, Morgan BP, Fontaine M: Identification and characterization of complement $\mathrm{C} 3$ receptors on human astrocytes. J Immunol 1996, I56(6):2247-2255.
25. Mao X, Moerman-Herzog AM, Wang W, Barger SW: Differential transcriptional control of the superoxide dismutase-2 kappaB element in neurons and astrocytes. J Biol Chem 2006, 28 I (47):35863-35872.

26. Xu Y, Gong B, Yang Y, Awasthi YC, Woods M, Boor PJ: Glutathione-S-transferase protects against oxidative injury of endothelial cell tight junctions. Endothelium 2007, I4(6):333-343.

27. Budas GR, Mochly-Rosen D: Mitochondrial protein kinase Cepsilon (PKCepsilon): emerging role in cardiac protection from ischaemic damage. Biochem Soc Trans 2007, 35(Pt 5): I052-1054.

28. Vargas JD, Herpers B, McKie AT, Gledhill S, McDonnell J, Heuvel M van den, Davies KE, Ponting CP: Stromal cell-derived receptor 2 and cytochrome b56I are functional ferric reductases. Biochim Biophys Acta 2003, I65 I (I-2): I I6- I23.

29. Riederer P, Sofic E, Rausch WD, Schmidt B, Reynolds GP, Jellinger K, Youdim MB: Transition metals, ferritin, glutathione, and ascorbic acid in parkinsonian brains. I Neurochem 1989 52(2):515-520

30. Foster N, Hulme SD, Barrow PA: Vasoactive intestinal peptide (VIP) prevents killing of virulent and phoP mutant Salmonella typhimurium by inhibiting IFN-gamma stimulated NADPH oxidative pathways in murine macrophages. Cytokine 2006, 36(3-4): | 34- I 40.

31. Stella MC, Vercelli A, Repici M, Follenzi A, Comoglio PM: Macrophage stimulating protein is a novel neurotrophic factor. Mol Biol Cell 200I, I 2(5): I 34I-I352.

32. Dunlap SM, Celestino J, Wang H, Jiang R, Holland EC, Fuller GN, Zhang W: Insulin-like growth factor binding protein 2 promotes glioma development and progression. Proc Natl Acad Sci USA 2007, I 04(28): I |736- I 174I.

33. Jiang $X$, Sorkin A: Coordinated traffic of Grb2 and Ras during epidermal growth factor receptor endocytosis visualized in living cells. Mol Biol Cell 2002, I3(5): I522-I535.

34. Puto LA, Pestonjamasp K, King CC, Bokoch GM: p2 I-activated kinase I (PAKI) interacts with the Grb2 adapter protein to couple to growth factor signaling. I Biol Chem 2003, 278(I I):9388-9393.

35. Braun H, Schulz S, Hollt V: Expression changes of somatostatin receptor subtypes sst2A, sst2B, sst3 and sst 4 after a cortical contusion trauma in rats. Brain Res 2002, 930(I-2): I9|-I99.

36. Zhang $Y$, Taveggia C, Melendez-Vasquez C, Einheber S, Raine CS Salzer JL, Brosnan CF, John GR: Interleukin-I I potentiates oligodendrocyte survival and maturation, and myelin formation. I Neurosci 2006, 26(47): $12174-12185$.

37. Loeffler M, Le'Negrate G, Krajewska M, Reed JC: Attenuated Salmonella engineered to produce human cytokine LIGHT inhibit tumor growth. Proc Natl Acad Sci USA 2007, I 04(3 I): | 2879- I 2883

38. Chicoine MR, Zahner M, Won EK, Kalra RR, Kitamura T, Perry A, Higashikubo R: The in vivo antitumoral effects of lipopolysaccharide against glioblastoma multiforme are mediated in part by Toll-like receptor 4. Neurosurgery 2007, 60(2):372-380.

39. Fournier DB, Gordon GB: COX-2 and colon cancer: potential targets for chemoprevention. J Cell Biochem Suppl 2000 , 34:97-102.

40. Takahashi K, Kawai T, Kumar H, Sato S, Yonehara S, Akira S: Roles of caspase-8 and caspase- 10 in innate immune responses to double-stranded RNA. J Immunol 2006, I 76(8):4520-4524.

4I. Weaver CV, Liu SP: Differentially expressed pro- and antiapoptogenic genes in response to benzene exposure: Immunohistochemical localization of p53, Bag, Bad, Bax, Bcl-2, and Bcl-w in lung epithelia. Exp Toxicol Pathol 2008, 59(5):265-272.

42. Han J, Flemington C, Houghton AB, Gu Z, Zambetti GP, Lutz RJ, Zhu $\mathrm{L}$, Chittenden T: Expression of bbc3, a pro-apoptotic $\mathrm{BH}$-only gene, is regulated by diverse cell death and survival signals. Proc Natl Acad Sci USA 200 I, 98(20): I I 3 | 8 - I I 323.

43. Vandenbroucke E, Mehta D, Minshall R, Malik AB: Regulation of endothelial junctional permeability. Ann N Y Acad Sci 2008 , I | 23: | 34- | 45 .

44. Dimayuga FO, Wang C, Clark JM, Dimayuga ER, Dimayuga VM, Bruce-Keller AJ: SOD I overexpression alters ROS production and reduces neurotoxic inflammatory signaling in microglial cells. J Neuroimmunol 2007, I 82(I-2):89-99. 
45. Cho H, Yun CW, Park WK, Kong JY, Kim KS, Park Y, Lee S, Kim BK: Modulation of the activity of pro-inflammatory enzymes, COX-2 and iNOS, by chrysin derivatives. Pharmacol Res 2004, 49(I):37-43.

46. Alves-Filho JC, de Freitas A, Spiller F, Souto FO, Cunha FQ: The role of neutrophils in severe sepsis. Shock 2008, 30(Suppl I):3-9.

47. Molina-Holgado F, Lledo A, Guaza C: Evidence for cyclooxygenase activation by nitric oxide in astrocytes. Glia 1995, I5(2): I67-I72.

48. Peng G, Zhang F, Zhang Q, Wu K, Zhu F, Wu J: Borna disease virus $P$ protein inhibits nitric oxide synthase gene expression in astrocytes. Virology 2007, 366(2):446-452.

49. Yue G, Lai PS, Yin K, Sun FF, Nagele RG, Liu X, Linask KK, Wang C, Lin KT, Wong PY: Colon epithelial cell death in 2,4,6-trinitrobenzenesulfonic acid-induced colitis is associated with increased inducible nitric-oxide synthase expression and peroxynitrite production. I Pharmacol Exp Ther 2001, 297(3):915-925

50. Akahane M, Akahane T, Matheny SL, Shah A, Okajima E, Thorgeirsson UP: Vascular endothelial growth factor-D is a survival factor for human breast carcinoma cells. Int J Cancer 2006 I I 8(4):84 |-849.

51. Holmes DI, Zachary I: Placental growth factor induces FosB and c-Fos gene expression via Flt-I receptors. FEBS Lett 2004, 557(I-3):93-98.

52. de Wilde J, De-Castro Arce J, Snijders PJ, Meijer CJ, RosI F, Steenbergen RD: Alterations in AP-I and AP-I regulatory genes during HPV-induced carcinogenesis. Cell Oncol 2008, 30(I):77-87.

53. Johannessen LE, Pedersen NM, Pedersen KW, Madshus IH, Stang E: Activation of the epidermal growth factor (EGF) receptor induces formation of EGF receptor- and Grb2-containing clathrin-coated pits. Mol Cell Biol 2006, 26(2):389-40I.

54. Kirkland RA, Saavedra GM, Franklin JL: Rapid activation of antioxidant defenses by nerve growth factor suppresses reactive oxygen species during neuronal apoptosis: evidence for a role in cytochrome c redistribution. J Neurosci 2007, 27(42): I|3|5-II326.

55. Mehlhase J, Gieche J, Widmer R, Grune T: Ferritin levels in microglia depend upon activation: modulation by reactive oxygen species. Biochim Biophys Acta 2006, I 763(8):854-859.

56. Hu G, Yang Q, Cui X, Yue G, Azaro MA, Wang HY, Li H: A highly sensitive and specific system for large-scale gene expression profiling. BMC Genomics 2008, 9:9.

57. Yue G, Wang HY, Luo M, Frikker D, Yin K, Neubauer J, Li H: Detection of A Large Number of Specific Gene Expression in A Few Number of Glioblastoma Cells. The American Society of Human Genetics 52nd Annual Meeting, Baltimore, Maryland, October 1519, 20022002 [http://www.ashg.org/genetics/abstracts/abs02/ f875.htm]

58. Yue G, Azaro M, Yang Q, Hu G, Luo M, Gao R, Li JY, Yang JM, Shi G, $\mathrm{Li} \mathrm{H}$ : Lipopolysaccharide regulates expression of cyclooxygenase-2 and tumor necrosis factor ligand superfamily member- I 4 in human glioma cell line T98G. The 2005 Annual Retreat on Cancer Research in New Jersey, Princeton, New Jersey, April 27, 2005 2005.

59. Hansson SR, Chen Y, Brodszki J, Chen M, Hernandez-Andrade E, Inman JM, Kozhich OA, Larsson I, Marsal K, Medstrand P, Xiang CC, Brownstein MJ: Gene expression profiling of human placentas from preeclamptic and normotensive pregnancies. Mol Hum Reprod 2006, I2(3): I69-179.

60. Pan W: A comparative review of statistical methods for discovering differentially expressed genes in replicated microarray experiments. Bioinformatics 2002, I 8(4):546-554.

61. Bonaventure P, Guo H, Tian B, Liu X, Bittner A, Roland B, Salunga R, Ma XJ, Kamme F, Meurers B, et al.: Nuclei and subnuclei gene expression profiling in mammalian brain. Brain Res 2002 943(I):38-47.
Publish with Bio Med Central and every scientist can read your work free of charge

"BioMed Central will be the most significant development for disseminating the results of biomedical research in our lifetime. "

Sir Paul Nurse, Cancer Research UK

Your research papers will be:

- available free of charge to the entire biomedical community

- peer reviewed and published immediately upon acceptance

- cited in PubMed and archived on PubMed Central

- yours - you keep the copyright

Submit your manuscript here:

http://www.biomedcentral.com/info/publishing_adv.asp
BioMedcentral 